\title{
PENGARUH LINGKUNGAN KERJA KABIN LOKOMOTIF TERHADAP TINGKAT STRES DAN BEBAN KERJA MENTAL MASINIS SECARA FISIOLOGIS
}

\author{
Caecilia Sri Wahyuning', Indah Rachmatiah S.S. ${ }^{2}$, Iftikar Z. Sutalaksana ${ }^{3}$ \\ ${ }^{1}$ Teknik Industri - Institut Teknologi Nasional, ${ }^{2}$ Teknik Lingkungan - Institut Teknologi Bandung, ${ }^{3}$ Teknik \\ dan Manajemen Industri - Institut Teknologi Bandung \\ Email:caecil@itenas.ac.id, indahrss@tl.itb.ac.id, siftikar@ymail.com
}

\begin{abstract}
Abstrak. Hasil kajian terhadap kecelakaan kereta api yang diindikasikan sebagai akibat human error masinis menunjukkan bahwa kesalahan tersebut diduga disebabkan oleh stres kerja dan beban kerja mental yang dialami oleh masinis. Salah satu sumber stres kerja masinis DaOp II Bandung adalah lingkungan fisik kabin lokomotif. Penelitian ini mengkaji dampak lingkungan fisik kabin lokomotif terhadap stres dan dan beban kerja mental masinis selama bertugas. Efek fisiologis stres adalah terjadinya reaksi biokimia untuk menyikapi stres yang menyebabkan peningkatan peningkatan denyut jantung, tekanan darah, dan saliva. Reaksi kimia tersebut dapat dilihat dari aktivitas Salivary $\alpha$-Amylase (SAA) sebagai respon biologis terhadap stres yang cepat dan berpengaruh terhadap sekresi SAA. Dampak dari sekresi tersebut terjadi peningkatan tekanan darah serta perubahan heart rate (HR) dan heart rate variability (HRV). Hasil pengukuran menunjukkan bahwa sebagian besar masinis memiliki tingkat stres tinggi $(92,8 \pm 69,9 \mathrm{kU} / \mathrm{L})$, bahkan saat baru tiba di stasiun untuk menjalankan tugas. Namun demikian hasil pengukuran HR dan HRV menunjukkan bahwa rata-rata denyut jantung $\left(\mathrm{HR}_{\text {mean }}\right)$ $(82,6 \pm 8,9)$ bpm dan SDNN $(63,8 \pm 98,4)$ masih dalam batas normal. Secara umum terdapat hubungan antara tingkat stres dengan temperatur saat menjalankan tugas $(p<0,05)$ dan kebisingan pada akhir tugas $(p<0,05)$. Korelasi hanya terjadi antara $\mathrm{HR}_{\text {mean }}$ dengan kebisingan $(\mathrm{p}<0,05)$ di awal tugas serta SDNN dengan kelembaban $(\mathrm{p}<0,05)$ di akhir tugas. Oleh karena itu dapat dikatakan bahwa lingkungan kabin lokomotif tidak mempengaruhi beban kerja mental masinis. Dari penelitian ini diperoleh kesimpulan bahwa tingkat stres masinis cenderung tinggi dan tingkat stres yang tinggi sebelum menjalankan tugas dapat disebabkan oleh aktivitas di luar tugas. Tingkat beban kerja mental masinis berada pada batas normal dan cenderung moderat. Dari penelitian ini juga ditemukan bahwa lingkungan kabin lokomotif selama bertugas tidak memberikan pengaruh terhadap peningkatan stres dan beban kerja mental selama dinasan.
\end{abstract}

Keywords: Masinis, Stres, Beban Kerja Mental, Salivary A-Amylase, Heart Rate Variability)

\begin{abstract}
The result from studies on railway accidents indicated as the result from human errors showed that the aforementioned error is allegedly caused by work stresses and mental workloads suffered by train drivers. One of the source for work stresses on drivers from Operational Region II Bandung is the physical environment of the locomotive's cabin. This study reviews the physiological process to stress and mental loads objectively in regards to physical environment of the locomotive's cabin. Driver's stress level from Operational Region II is measured based from the activity of Salivary $\alpha$-Amylase (SAA) and mental workload is measured through heart Rate $(H R)$ and heart rate variability (HRV) Measurement shows that most drivers have high stress level $(>60 \mathrm{kU} / \mathrm{L})$ even when they have just arrived at the station for assignment $(92.8 \pm 69.9 \mathrm{kU} / \mathrm{L})$. Nevertheless, the $H R$ and HRV measurement shows that the average heart rate $\left(H R_{\text {mean }}\right)(82.6 \pm 8.9)$ bpm and the measured SDNN value $(63.8 \pm 98.4)$ is on the normal limit. Generally speaking, there is a relation between temperatures during assignment $(p=0.008)$ and noise by the end of assignment $(p<0.05)$. Even so, considering that most of the drivers suffered stress even before the start of the assignment, therefore the source of stresses is from the activity before the assignment. Mental workload conditions of drivers, both according to SDNN and HRmean is on normal range. In relation to the physical environment of locomotive's cabin, correlation occurred only on $H R_{\text {mean }}$ with noise at the start of the assignment $(p<0.05)$ and moisture to SDNN by the end of assignment $(p<$ 0.05). Therefore it's safe to say that mental workload is not affected by locomotive cabin's environment. From this study, it is concluded that the stress level of drivers are considerably high. The height of the stress is proven with 56\% of drivers with Salivary $\alpha$-Amylase (SAA) levels way beyond the threshold. Since this happened even before the assignment, this could be caused by an activity other than the assignment. From this study, it is also found that journeys during assignment does not contribute significantly to the increase of the stress level. Mental
\end{abstract}


workload levels, through physiological response, are objectively normal to moderate, while the observation from HRV shows a tendency of normal mental workload

\section{Keywords: Train Driver, Stress, Mental Workload, Salivary A-Amylase, Heart Rate Variability}

\section{Pendahuluan}

Berdasarkan kajian terhadap 36 laporan hasil investigasi Komite Nasional Kecelakaan Transportasi (KNKT) terhadap kasus kecelakaan kereta api yang berada di wilayah Pulau Jawa dan Pulau Sumatera selama tahun 2003-2010, terdapat 29 kecelakaan yang diindikasikan terkait dengan human error. Dari kajian tersebut 13 dari kecelakaan ditengarai terkait erat dengan kesalahan masinis. Dalam sebuah kecelakaan transportasi human error seringkali menjadi dugaan awal sebagai penyebab kecelakaan. Kecelakaan yang diindikasi sebagai akibat kesalahan masinis perlu diperhatikan dari berbagai aspek yang lebih luas, karena kecelakaan tersebut tidak murni disebabkan oleh human error (Williamson dkk., 2011).

Faktor-faktor yang berpengaruh terhadap masinis saat menjalankan kereta api antara lain adalah (1) personel, (2) kereta, (3) lintasan dan (4) lingkungan (kabin kemudi dan cuaca) (Dorrian dkk., 2006). Masinis dituntut untuk memahami, memperkirakan, mengantisipasi, dan bertindak atas situasi saat ini dan yang akan datang, dengan mempertimbangkan kondisi lingkungan (Zoer dkk., 2014). Karakteristik kerja sebagaimana dijelaskan di atas tentunya akan merupakan sumber stres (stressor) yang bersifat spesifik (context-specific).

Stres merupakan respon pertahanan tubuh terhadap ketidakseimbangan antara tuntutan (demand) dengan sumber daya (resource) yang tersedia (Landy dan Conte, 2013). Respon ini merupakan mobilisasi awal ketika tubuh mendapat tantangan dari sumber stres (stressor) (Martinussen dan Hunter, 2010). Efek fisiologis stres adalah terjadinya reaksi biokimia untuk menyikapi stres secara positif (eustress) atau negatif (distress), yang menyebabkan peningkatan aktivitas saraf simpatik yang berdampak pada peningkatan denyut jantung, tekanan darah, dan saliva. Kondisi ini menggambarkan respon fight (bertahan terhadap stres) atau flight (menghindar dari sumber stres) (Taylor, 2009).

Berdasarkan hasil identifikasi sumber stres kerja masinis diperoleh delapan faktor sumber stres masinis yang dominan, yaitu lingkungan kabin lokomotif, tuntutan mental, beban kerja dan tanggung jawab, peluang kerja, pekerjaan di masa depan, masalah di tempat kerja, persyaratan kerja, dan rentang kendali (Wahyuning dan Desryanti., 2011). Dari kedelapan faktor sumber stres tersebut, sumber stres yang berkaitan dengan tugas secara langsung adalah lingkungan kerja, tuntutan mental, serta beban kerja dan tanggung jawab. Sama halnya dengan yang diungkapkan oleh Dorrian dkk., (2007), bahwa lingkungan (pencahayaan, temperatur, kebisingan, dan cuaca) merupakan salah satu faktor yang mempengaruhi kompleksitas dan beban kerja masinis saat menjalankan kereta selain faktor individu, kereta, dan lintasan.

Menurut Selye (1950) dalam Landy dan Conte (2013) pendekatan fisiologis terhadap stres merupakan perubahan non-spesifik dalam sistem biologis yang terjadi ketika mendapat rangsangan ketidaknyaman dan ketidakamanan. Stres diperlakukan sebagai respon fisiologis umum yang terjadi pada tiga fase alamiah yang melibatkan tahap awal (aktivasi Sympathetical Adrenal MedullarySAM) dilanjutkan dengan tahap perlawanan (aktivasi adrenal cortical) dan tahap akhir dari kelelahan (reaktivasi SAM) (Cox dan Griffiths, 2005).

Salah satu penanda stres melalui penanda biologis (biomarker) dapat diukur melalui saliva. Sesuai dengan kondisi lapangan penelitian, maka pengukuran melalui saliva lebih mudah dibandingkan melalui darah dan urin. SAA merupakan respon biologis yang sangat cepat dan kemungkinan terdapat pengaruh jangka panjang terhadap sekresi SAA (Rohleder dan Nater, 2009).

Sebuah eksperimen dilakukan terhadap tingkat stress 15 responden di ergometer. Pengukuran dilakukan terhadap kortisol, SAA, dan denyut jantung (Yamaguchi dkk, 2003). Hasil penelitian tersebut menunjukkan adanya korelasi antara SAA dan denyut jantung. Subyek yang mengalami perubahan sedikit denyut jantung mengalami juga perubahan SAA yang kecil. Hal ini dapat terjadi karena peningkatan denyut jantung dipengaruhi oleh sistem saraf simpatik yang memicu sekresi hormon epinefrin dan norepinefrin untuk menjaga tubuh ketika terjadi situasi stres (Scanlon dan Sanders, 2007; Taelman dkk., 2008, Mulrine dkk., 2011). Dampak dari sekresi tersebut terjadi peningkatan tekanan darah serta perubahan heart rate (HR) dan heart rate variability (HRV), di mana proses ini dikenal sebagai reaksi "fight or flight" (Taelman dkk, 2009).

Secara umum peningkatan HRdan penurunan HRV berkaitan dengan peningkatan tingkat beban kerja. Pengukuran denyut jantung dan 
variabilitasnya merupakan metoda pengukuran yang sering digunakan untuk mengukur beban kerja mental secara akurat (Hancock dan Meshkati, 1988; Taelman dkk, 2009).

Masih belum banyak dilakukan kajian terhadap tingkat stres dan beban kerja mental masinis, utamanya kajian terhadap tingkat stres dan beban kerja mental secara fisiologis. Pada penelitian ini akan dikaji pengaruh lingkungan kabin lokomotif terhadap tingkat stres dan beban kerja mental masinis. Penelitian ini merupakan penelitian lapangan (field study) yang mengobservasi secara langsung tingkat stres dan beban kerja mental masinis selama menjalankan tugas.

\section{Metode Penelitian}

Penelitian ini dilakukan dengan melakukan observasi lingkungan kabin lokmotif dan pengukuran terhadap perubahan tingkat stres pada masinis. Skema waktu pengukuran tingkat stres tersebut dapat dilihat pada Gambar 2.1. Separuh pertama perjalanan tugas adalah perjalanan dari stasiun keberangkatan sampai dengan stasiun tempat masinis berhenti di tengah perjalanan tugas. Separuh kedua perjalanan tugas adalah dari stasiun tempat masinis berhenti di tengah perjalanan tugas sampai dengan stasiun tujuan.

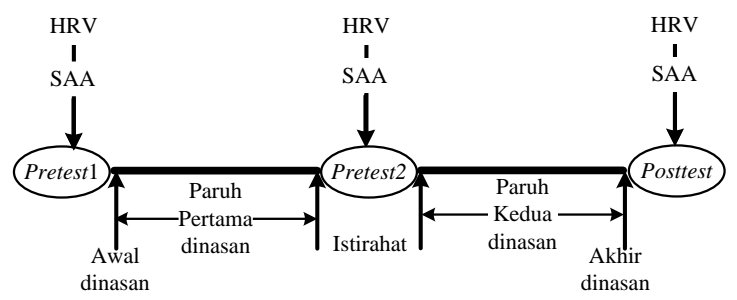

Gambar 1. Skema Penelitian

Metode yang digunakan dalam penelitian ini adalah:

\subsection{Observasi Lingkungan Fisik Kabin Lokomotif}

Observasi ini dilakukan untuk mendapatkan gambaran lingkungan kerja masinis selama menjalankan tugas, yang dilihat dari kondisi lingkungan kabin lokomotif. Pengukuran lingkungan fisik kabin lokomotif dilakukan selama tugas berlangsung dengan interval 15 menit. Parameter yang diukur adalah temperatur dan kelembaban, intensitas suara, dan intensitas cahaya kabin, dengan menggunakan alat ukur temperatur dan kelembaban (Termometer dan Humidity Level Meter), kebisingan (Sound Level Meter (SLM) dengan skala A), dan intensitas cahaya (Lux Meter).

\subsection{Pengukuran Tingkat Stres dan Beban Kerja Mental}

Instrumen yang digunakan dalam penelitian ini adalah sebagai berikut:

1. Konsentrasi Salivaryo-Amylase (SAA)

Pada penelitian ini instrumen yang digunakan dalam pengukuran tingkat stres untuk mengukur konsentrasi Salivary $\alpha$-Amylase adalah Cocoro Meter (Nipro. Jepang). Yamaguchi dkk. (2004) melakukan validasi terhadap metoda ini untuk menilai kelelahan para pengemudi, dan menyatakan bahwa instrumen ini layak untuk digunakan sebagai alat ukur tingkat stres. Hasil kalibrasi instrumen ini menunjukkan R2 $=0,94$, (Yamaguchi dkk., 2004), yang dilakukan untuk memverifikasi keakuratan. Rancangan eksperimen untuk penilaian tingkat stres melalui SAA ditunjukkan pada Tabel 1.

Tabel 1. Rancangan Eksperimen Tingkat Stres Melalui SAA

\begin{tabular}{ccccc}
\hline $\begin{array}{c}\text { Pretest1 } \\
\text { score }\end{array}$ & Treatment & $\begin{array}{c}\text { Pretest2 } \\
\text { score }\end{array}$ & Treatment & $\begin{array}{c}\text { Post-test } \\
\text { score }\end{array}$ \\
\hline$\overline{S A A_{1}}$ & $\begin{array}{c}\text { paruh } \\
\text { pertama } \\
\text { perjalanan }\end{array}$ & $\overline{S A A_{2}}$ & $\begin{array}{c}\text { paruh } \\
\text { kedua } \\
\text { perjalanan }\end{array}$ & $\overline{S A A_{3}}$ \\
& & & \\
$\begin{array}{c}\text { Treatment } \\
\text { effect }\end{array}$ & $\left(\overline{S A A_{2}}-\overline{S A A_{1}}\right)$ & $\left(\overline{S A A_{3}}-\overline{S A A_{2}}\right)$ \\
\hline
\end{tabular}

2. Heart Rate (HR) dan Heart Rate Variability (HRV)

HRV dapat digunakan untuk menilai tingkat stres psikososial (Paritala, 2009; Tarvainen dkk., 2014). Penggunaan Heart Rate Monitor lebih mudah untuk digunakan sebagai real time recording (Paritala, 2009). Instrumen yang digunakan dalam pengukuran tingkat stres untuk mengukur HRV adalah POLAR RS800 Heart Rate Monitor (Polar Electro Inc., Lake Success, NY), yaitu alat pengukur denyut jantung. Rancangan eksperimen untuk penilaian tingkat beban mental ditunjukkan pada Tabel 2.

Tabel 2. Rancangan Eksperimen Tingkat Stres Melalui HR dan HRV

\begin{tabular}{ccccc}
\hline $\begin{array}{c}\text { Pretest1 } \\
\text { score }\end{array}$ & Treatment & $\begin{array}{c}\text { Pretest2 } \\
\text { score }\end{array}$ & Treatment & $\begin{array}{c}\text { Post-test } \\
\text { score }\end{array}$ \\
\hline$\overline{H R V_{1}}$ & $\begin{array}{c}\text { paruh } \\
\text { pertama } \\
\text { perjalanan }\end{array}$ & $\overline{H R V_{2}}$ & $\begin{array}{c}\text { paruh } \\
\text { kedua } \\
\text { perjalanan }\end{array} \overline{H R V_{3}}$ \\
\multicolumn{2}{c}{$\begin{array}{c}\text { Treatment } \\
\text { effect }\end{array}$} & $\left(\overline{H R V_{2}}-\overline{H R V_{1}}\right)$ & $\left(\overline{H R V_{3}}-\overline{H R V_{2}}\right)$ \\
\hline
\end{tabular}

\subsection{Partisipan}

Populasi dalam penelitian ini adalah masinis di Daerah Operasional II Bandung yang berjumlah 
160 masinis, dan sampling yang digunakan dalam tahap penelitian ini adalah non-probability sampling. Peneliti mendapatkan kesempatan dari PT KAI untuk melakukan observasi selama 30 hari kerja, dan peneliti dapat melakukan observasi pada dua tugas dalam satu hari. Namun demikian tidak semua perjalanan tersebut dapat dilakukan observasi dengan baik. Mengingat peneliti sangat bergantung pada kondisi lapangan yang sebenarnya. Kriteria subyek yang dipilih dalam tahap ini adalah memiliki T-62 (brevet masinis) dan T-63 (surat izin masuk lokomotif) dan telah satu tahun sebagai masinis.

\section{Hasil dan Pembahsan}

Hasil dan pembahasan terhadap hasil observasi dan pengukuran lingkungan fisik dan aspek fisiologis masinis adalah sebagai berikut:

\subsection{Lingkungan Fisik Kabin Lokomotif}

Hasil pengukuran lingkungan fisik kabin lokomotif selama menjalankan tugas dapat dilihat pada Tabel 3.

Tabel 3. Hasil Pengukuran Lingkungan Fisik Kabin Lokomotif

\begin{tabular}{ccccc}
\hline $\begin{array}{c}\text { Paruh } \\
\text { perjala- } \\
\text { nan }\end{array}$ & $\begin{array}{c}\text { Tempe- } \\
\text { ratur } \\
\left({ }^{\boldsymbol{O}} \boldsymbol{C}\right)\end{array}$ & $\begin{array}{c}\text { Kelem- } \\
\text { baban } \\
(\%)\end{array}$ & $\begin{array}{c}\text { Intensitas Intensitas } \\
\text { suara } \\
(\boldsymbol{d B A})\end{array}$ & $\begin{array}{c}\text { cahaya } \\
(\text { Lux })\end{array}$ \\
\hline Pertama & 27,34 & 69,73 & 82,32 & 75,83 \\
\hline Kedua & 31,48 & 64,73 & 84,84 & 67,04 \\
\hline
\end{tabular}

Peningkatan temperatur pada kabin lokomotif disebabkan oleh posisi kabin lokomotif, lingkungan luar kabin lokomotif, serta kondisi lintasan. Temperatur lebih tinggi pada saat posisi kabin lokomotif berada di belakang mesin (lokomotif panjang) dan saat melintasi lintasan berbukit (menanjak). Peningkatan temperatur di kabin lokomotif dapat disebabkan oleh cahaya matahari yang langsung masuk ke kabin dan sirkulasi udara yang tidak berjalan dengan baik sementara di kabin tidak terdapat alat yang dapat mengatur kondisi temperatur.

Tugas manisis menuntut tingkat konsentrasi yang tinggi, dan masinis sangat mengandalkan pendengaran selama mengemudikan lokomotif. Dalam bertugas Masinis harus berkonsentrasi agar dapat berkomunikasi dengan baik dengan asisten masinis, PPKA atau antar kereta melalui radio telekomunikasi. Akan tetapi saat lokomotif melintasi lintasan berbukit (menanjak), tenaga yang diperlukan untuk melakukan dorongan semakin besar, sehingga menyebabkan peningkatan intensitas suara. Kondisi ini dapat menyebabkan masinis memerlukan usaha yang lebih besar untuk dapat berkomunikasi dengan baik.

Kondisi lokomotif saat menjalankan tugas pagi hari menuju timur dan sore hari menuju barat masinis berhadapan langsung dengan arah datang cahaya matahari. Pada lokomotif yang tidak memiliki penghalang silau, masinis menggunakan koran pada kaca bagian atas untuk mengatasi masalah tersebut.

Masinis memanfaatkan jendela pada kabin lokomotif untuk meningkatkan sirkulasi udara. Saat Fungsi penyejuk udara pada kabin lokomotif perlu dioptimalkan karena observasi kondisi sistem pendingin kabin tidak berfungsi. Oleh karena itu masinis mengandalkan kipas angin atau jendela yang dibuka, dan kondisi ini berdampak pada tingkat kebisingan. Dengan demikian maka perlu dirancang kabin lokomotif yang dapat mengurangi intensitas kebisingan dan panas yang masuk ke dalam kabin, baik dari desain lokomotif maupun sistem permesinan pada lokomotif.

\subsection{Tingkat Stres dan Beban Mental Masinis}

1. Konsentrasi Salivaryo-Amylase (SAA)

Bila mengacu pada batasan tingkat stres (Yamaguchi dkk., 2004), maka persentase masinis untuk setiap tingkat stres dapat dilihat pada Tabel 3.2. Sebanyak 70,6\% masinis memilik tingkat stres sangat tinggi (> $60 \mathrm{kU} / \mathrm{l})$ sebelum bertugas, $58,8 \%$ masinis sesaat setelah menyelesaikan separuh perjalanan tugas dan 55,9\% masinis setelah menyelesaikan tugas. Masinis yang mamiliki tingkat stres di atas batas/norma yang seharusnya sebelum menjalankan tugasnya, dapat disebabkan oleh kegiatan sebelumnya sebagai aktivitas di luar tugas.

Tabel 4. Persentase Masinis Pada Setiap Tingkat Stres (N=34)

\begin{tabular}{c|ccc}
\hline \multirow{2}{*}{ Tingkat stres } & \multicolumn{3}{|c}{ Waktu pengambilan sampel } \\
\cline { 2 - 4 } & Pretest1 & Pretes2 & Post-test \\
\hline $0-15 \mathrm{kU} / 1$ & $8,8 \%$ & $5,9 \%$ & $8,8 \%$ \\
$15-30 \mathrm{kU} / 1$ & $8,8 \%$ & $8,8 \%$ & $8,8 \%$ \\
$30-45 \mathrm{kU} / 1$ & $5,9 \%$ & $8,8 \%$ & $17,6 \%$ \\
$45-60 \mathrm{kU} / 1$ & $5,9 \%$ & $17,6 \%$ & $8,8 \%$ \\
$>60 \mathrm{kU} / 1$ & $\mathbf{7 0 , 6 \%}$ & $\mathbf{5 8 , 8 \%}$ & $\mathbf{5 5 , 9 \%}$ \\
\hline
\end{tabular}

Median konsentrasi SAA 80,00 kU/1 dan IQR (37,5-137) kU/1. Gambar $3.1 \quad$ (kiri) menunjukkan terdapat banyak data SAA yang lebih tinggi dari $137 \mathrm{kU} / \mathrm{l}$ (Q3). Kondisi ini menggambarkan bahwa distribusi data cenderung lebih besar dari nilai median (positive skewness) atau konsentrasi SAA cenderung tinggi. Pada Gambar 3.1. (kanan) 
menunjukkan bahwa terjadi peningkatan median dan penurunan IQR pada SAA2, serta penurunan median dan peningkatan IQR pada SAA3 dengan satu data outlier.
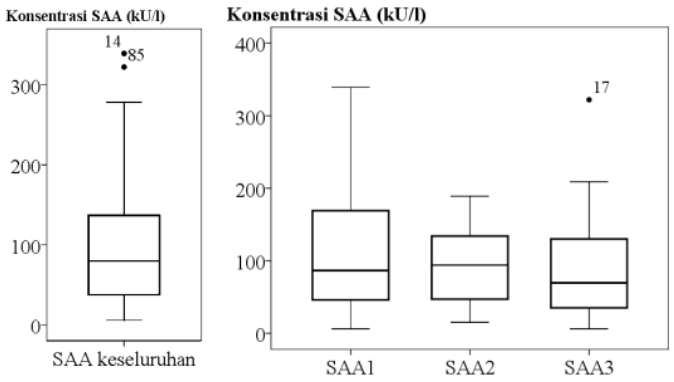

Gambar 2. Sebaran Data SAA

Berdasarkan rancangan eksperimen quasi (Tabel 3.2) nilai $\Delta$ pada separuh pertama tidak menunjukkan peningkatan (Treatment effect $=-16,00 \mathrm{kU} / \mathrm{l})$. Sedangkan pada separuh kedua terdapat peningkatan yang kecil (cenderung tetap) (Treatment effect= $0,03 \mathrm{kU} / \mathrm{l})$. Dengan demikian maka tingkat stres masinis tidak terpengaruh selama menjalankan dinasan baik pada separuh pertama maupun separuh kedua perjalanan dinasan.

Tidak terdapat perbedaan nilai SAA sebelum $(p=0,140) \quad$ dan setelah $\quad(p=0,967)$ menjalankan tugas, baik pada paruh pertama maupun kedua tugas. Namun demikian permasalahan stres pada masinis merupakan hal penting yang perlu dikaji, mengingat satu orang masinis bertanggung jawab penuh terhadap keselamatan satu rangkaian kereta, serta kelancaran operasional kereta api di lintasan yang dilaluinya.

Tabel 5. Treatment Effect Tingkat Stres Melalui SAA

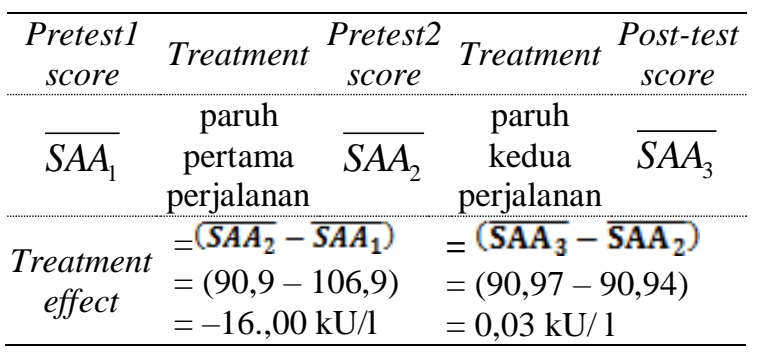

Hasil kajian Yamaguchi dan Sakakima (2007) terhadap 20 responden untuk mengemudi pada sebuah simulator, menunjukkan terjadi peningkatan nilai konsentrasi SAA driving dibandingkan dengan $\mathrm{SAA}_{\text {base }}$ pada dua percobaan. Responden sulit untuk mengemudi dan mengoperasikan perangkat pada waktu bersamaan, di mana kemampuan mengemudi dan konsentrasi selama mengemudi akan menurun pada saat diikuti dengan aktivitas mengendalikan sistem navigasi. Berkaitan dengan kerja masinis, maka tugas masinis mengendalikan kereta yang disertai dengan komunikasi dan melihat Gapeka memungkinkan untuk terjadi peningkatan SAA.

Tidak adanya perbedaan tingkat stres (SAA) mengindikasikan adanya kemungkinan bahwa pada saat pengukuran masinis tidak terpengaruh faktor dominan stres kerja. Hal ini dapat terjadi karena masinis sudah beradaptasi dengan lingkungan dan tugas sebagai masinis, selain itu masinis sudah memahami dan menguasai kondisi lintasan dan kondisi geografis di sekitar lintasan.

Kondisi di lapangan menunjukkan bahwa 22 dari 35 masinis dalam keadaan sangat stres sebelum tugas. Hal lain yang memungkinkan terjadi karena SAA berkaitan dengan irama sirkadian tubuh. Dari beberapa kajian yang dilakukan Ferguson dkk., (1973) dalam Rohleder dan Nater (2009) menunjukkan bahwa yang konsentrasi SAA pagi hari lebih rendah dan empat kajian lainnya menyatakan lebih tinggi pada sore hari. Penurunan tingkat SAA pada pagi hari dan meningkat pada sore dan malam hari (Rohleder dkk., 2004).

Pada tataran individu, terdapat dua masinis memiliki tingkat stres $3-5$ kali batas atas SAA.Walaupun tidak diuji secara stastitik, terapat individu engan karakteristik seperti ini. Kedua masinis ini berusia 40 dan 39 tahun dengan pengalaman sebagai masinis selama 16 dan 19 tahun. Pada saat observasi masinis tersebut menjalankan tugas malam hari (20.45 - 00.30) dan (02.00 06.00).Oleh karena itu hal ini perlu diperhatikan karena terdapat kemungkinan perlu dilakukan assessment dengan lebih seksama terhadap individu tersebut untuk mengidentifikasi faktor yang dapat menyebabkan tingginya tingkat stres individu tersebut.

2. Heart Rate (HR) dan Heart Rate Variability (HRV)

3. Hasil dari kedua indikator dari kerja jantung akibat stres adalah adalah:

\section{a. Heart Rate}

Rata-rata median dan IQR pada ketiga kelompok $\mathrm{HR}_{\text {mean }}$ hampir sama. Gambar 3.2 menunjukkan bahwa data $\mathrm{HR}_{\text {mean } 1}$ dan $\mathrm{HR}_{\text {mean } 2}$ cenderung lebih kecil dari nilai median (negative skewness). 


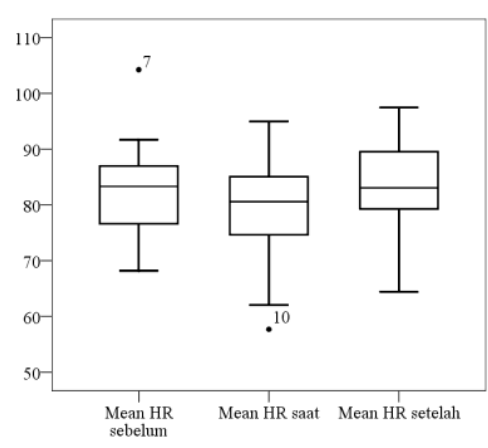

Gambar 3. Sebaran data $\mathbf{H R}_{\text {mean }}$

Pada perjalanan separuh pertama perjalanan tugas siang hari $\mathrm{HR}_{\text {meanl }}$ lebih tinggi dari $\mathrm{HR}_{\text {mean2 }}$ dan pada separuh perjalanan kedua nilai $\mathrm{HR}_{\text {mean } 2}$ lebih rendah dariHR $\mathrm{R}_{\text {means. Dengan demikian }}$ secara umum terjadi perubahan $\mathrm{HR}_{\text {mean }}$ pada saat masinis menjalankan tugas.

Berdasarkan rancangan eksperimen quasi nilai $\Delta \mathrm{HR}_{\text {mean }}$ pada paruh pertama perjalanan tidak terjadi peningkatan (treatment effect $=-3 \cdot 00 / \mathrm{min}$ ). Dengan demikian maka beban kerja mental masinis tidak dipengaruhi oleh perjalanan pada separuh pertama perjalanan. Akan tetapi terjadi peningkatan (Treatment effect= 3,92/min) pada paruh kedua yang mengindikasi terjadi peningkatan beban kerja mental.

Tabel 6. Treatment Effect Tingkat Stres Melalui HR

\begin{tabular}{|c|c|c|c|}
\hline $\begin{array}{r}\text { Pret } \\
\text { sco }\end{array}$ & $\begin{array}{c}\text { Preatment } \begin{array}{c}\text { Prest } 2 \\
\text { score }\end{array} \\
\text { Treats }\end{array}$ & Trea & $\begin{array}{r}P o \\
\text { Sc }\end{array}$ \\
\hline & $\begin{array}{l}\text { paruh } \\
\text { pertama } \\
\text { perjalanan }\end{array}$ & $\begin{array}{c}\text { paruh } \\
\text { kedua } \\
\text { perjalanan }\end{array}$ & $n_{3}$ \\
\hline effe & $\begin{array}{l}\left.-\overline{\text { HRmean }_{1}}\right) \\
\text { min } \\
\text { min }\end{array}$ & $\begin{array}{l}=(\overline{\mathrm{HR}} \\
=(83 \\
=3,9\end{array}$ & 78 \\
\hline
\end{tabular}

Namun demikian, secara statistik perubahan nilai $\mathrm{HR}_{\text {mean }}$ menunjukkan terdapat perbedaan pada paruh pertama $(p<0,05)$ dan kedua perjalanan $(p<$ $0,05)$. Peningkatan $\mathrm{HR}_{\text {mean }}$ mengindikasi konsekuensi stres secara psikologis (Hjorskov dkk., 2004 dalam Paritala, 2009; Landy dan Conte, 2013) sebagai efek dari sekresi hormon epinefrin dan norepinerin (Scanlon dan Sanders, 2007). Sekresi ini meningkat sebagai bentuk defense reaction terhadap stressor (Kroemer dkk., 2010). Bila dilihat dari $\mathrm{HR}_{\text {mean }}$ maka terdapat perbedaan yang signifikan terhadap perubahan $\mathrm{HR}_{\text {mean. }}$. Dengan demikian terjadi perubahan $\mathrm{HR}_{\text {mean }}$ selama masinis menjalankan tugas.

b. Heart rate variability dengan indikator SDNN

Median $\mathrm{SDNN}_{1}$ dan $\mathrm{SDNN}_{2}$ hampir sama akan tetapi IQR SDNN2 lebih besar 1,71 kali dari $\mathrm{SDNN}_{1}$. Pada $\mathrm{SDNN}_{2}$ terdapat dua outlier sedangkan $\mathrm{SDNN}_{3}$ terdapat dua nilai ekstrem, walaupun median dan IQR $\mathrm{SDNN}_{3}$ meningkat 1,76 kali dari IQR $\mathrm{SDNN}_{2}$. Whisker, outlier dan nilai ekstrem pada $\mathrm{SDNN}_{2}$ dan $\mathrm{SDNN}_{3}$ menunjukkan bahwa distribusi data kedua kelompok data ini cenderung lebih besar dari median (positive skewness) (Gambar 4. kiri).

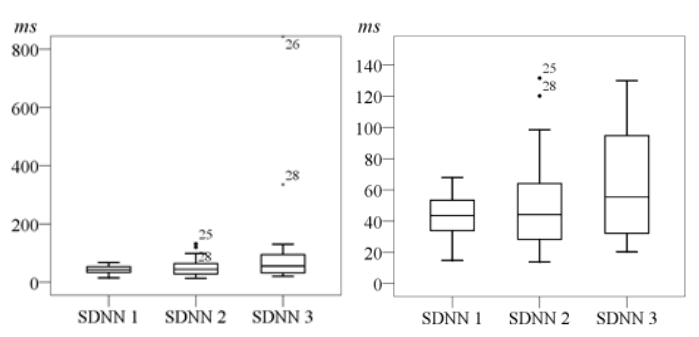

Gambar 4. Sebaran Data SDNN

Penurunan SDNN mengindikasi terjadi peningkatan beban kerja mental pada saat beban kerja fisik dapat diabaikan (Gambar 3.3 kanan). Sumber stres inheren dan lingkungan yang berbeda meningkatkan aktivasi simpatik dengan yang ditunjukan dengan penurunan HRV dan peningkatan HR (Uusitalo dkk., 2011). Terdapat $50 \%$ masinis pada tugas pertama dan $39,9 \%$ masinis pada tugas kedua mengalami penurunan SDNN. Namun demikian, bila melihat persentase tersebut maka secara umum perjalanan tugas tidak mempengaruhi SDNN.

Berdasarkan rancangan eksperimen quasi nilai $\Delta$ SDNN pada paruh pertama dan kedua perjalanan dinasan terdapat peningkatan (Treatment effect $=12,64$ ms dan 43,40 ms). Kondisi ini menunjukkan bahwa beban kerja mental masinis tidak dipengaruhi oleh perjalanan pada separuh pertama perjalanan maupun separuh kedua perjalanan dinasan (Tabel 7.).

Tabel 7. Treatment Effect Tingkat Stres Melalui HR 


\begin{tabular}{|c|c|c|c|}
\hline $\begin{array}{c}\text { Pretest1 } \\
\text { score }\end{array}$ & $\begin{array}{c}\text { Treatment } \begin{array}{c}\text { Pretest } 2 \\
\text { score }\end{array} \\
\text { The }\end{array}$ & Treatment & $\begin{array}{c}\text { Post-test } \\
\text { score }\end{array}$ \\
\hline$S D N N_{1}$ & $\begin{array}{l}\text { paruh } \\
\text { pertama } \\
\text { perjalanan }\end{array}$ & $\begin{array}{c}\text { paruh } \\
\text { kedua } \\
\text { perjalanan }\end{array}$ & $\mathrm{SDNN}_{3}$ \\
\hline $\begin{array}{c}\text { Treatmen } \\
\text { effect }\end{array}$ & $\begin{aligned} & =\left(\overline{S D N N_{2}}-\overline{S D N N}\right. \\
& =(51.85-43.21) \\
& =12.64 \mathrm{~ms}\end{aligned}$ & $\begin{aligned} & =\left(\overline{\text { SDNN }_{3}}\right. \\
& =(94.98- \\
& =43.40 \mathrm{~m}\end{aligned}$ & $\begin{array}{l}-\overline{S D} \\
-51.5 \\
\mathrm{~ns}\end{array}$ \\
\hline
\end{tabular}

Tidak terdapat perbedaan tingkat beban mental yang terjadi pada separuh tugas pertama $(p=0,116)$ dan kedua $(p=$ $0,151)$, namun demikian terdapat masinis mengalami penurunan SDNN. Oleh karena itu, mengingat bahwa aspek keselamatan merupakan salah satu pilar utama dari operasional perkeretaapian, maka hal ini masih perlu mendapat perhatian.

Peningkatan rata-rata (Coefisien of Variation) $\mathrm{CV}_{\text {SDNN }}$ terjadi mulai dari sebelum memulai tugas, saat tugas sampai dengan setelah menyelesaikan setengah perjalanan. Kondisi ini terjadi baik pada separuh pertama dan kedua tugas. Semakin kecil $\mathrm{CV}_{\text {SDNN }}$ semakin baik karena menunjukkan nilai dispersi yang terjadi pada $\mathrm{RR}_{\text {mean }}$ semakin kecil atau konsisten/homogen (Paritala, 2009; Nunan dkk., 2010). Dengan demikian berdasarkan indikator $\mathrm{CV}_{\text {SDNN }}$ terdapat indikasi peningkatan beban kerja mental. Berdasarkan penurunan SDNN dan $\mathrm{CV}_{\text {SDNN }}$ secara individual maka hanya $10,7 \%$ masinis yang tidak mengalami penurunan. Sedangkan $21,4 \%$ masinis mengalami peningkatan. Kondisi ini menunjukkan bahwa selama menjalankan tugas terjadi ketidakkonsistenan denyut jantung dengan dispersi yang besar. Hal ini dapat disebabkan karena denyut jantung mengikuti irama sirkadian, di mana denyut jantung yang lebih tinggi terjadi pada siang hari dibandingkan malam hari (Bourdreau dkk., 2011). Sehingga terdapat kemungkinan bahwa peningkatan SDNN dan $\mathrm{CV}_{\text {SDNN }}$ terjadi pada saat denyut jantung harus rendah tetapi masinis dalam keadaan bekerja.

Penelitian Park dkk, (2007) terhadap 366 pria dan 271 wanita Korea berusia $45 \pm 10,7$ tahun dihasilkan rentang SDNN $35,9 \pm 15,5$ (ms). Berdasarkan 27 kajian ditetapkan rentang normal SDNN 32-93 (ms) (Nunan dkk, 2010), sedangkan
Kim dan Woo (2011) rentang normal SDNN adalah $39,6 \pm 22,1 \mathrm{~ms}$ yang dikaji dari 3085 penduduk Korea. Bila melihat pada kedua rentang tersebut, maka ratarata SDNN hasil pengukuran mendekati pada kedua rentang tersebut.

Berkaitan dengan jam tugas masinis di malam, tengah malam dan dini hari, HRV dapat digunakan sebagai penanda modulasi otonomik jantung (Bourdreau dkk., 2011). Pada irama sirkadian interval $\mathrm{RR}_{\text {mean }}$ lebih tinggi pada malam hari dibandingkan siang hari. Penelitian Bourdreau dkk., (2011) mengungkapkan terdapat efek proses tidur-bangun dan proses sirkadian pada ritmis jantung, serta interaksi di antara proses-proses tersebut.

Beban kerja didefinisikan sebagai sejumlah sumber yang diperlukan untuk menjalankan tugas, yang ditetapkan dalam tiga tipe, yaitu: beban kerja visual beban kerja motorik, dan beban kerja mental (Silva, 2014). Bila melihat tugas masinis, maka beban kerja masinis mencakup ketiga tipe beban kerja tersebut. Beban kerja visual karena masinis harus melihat dan merespon berbagai tipe informasi (display, sinyal, marka, dan sebagainya), beban kerja motorik karena harus mengendalikan tuas dan pedal, serta beban kerja mental karena harus memproses berbagai tipe informasi. Secara spesifik dapat dikatakan bahwa beban kerja masinis melibatkan proses neurofisiologi, perseptual, dan kognitif (Silva, 2014) mengingat proporsi kapasitas pemrosesan informasi yang digunakan untuk melaksanakan tugas lebih besar.

Analisis tugas pada penelitian Zoer dkk. (2014) mengungkapkan bahwa masinis mengalami beban mental yang tertinggi sebelum tiba dan meninggalkan stasiun.Pada penelitian ini kondisi ini tergambar pada nilai SAA yang tinggi dari hasil pengukuran sebelum dan setelah menjalankan tugas.

Penelitian Zoer dkk.(2014) mengungkapkan bahwa sebuah sinyal kuning ganda, yang memerintahkan masinis untuk memperlambat karena sinyal berikut bisa menjadi merah, juga meningkatkan beban mental. Beban mental, yang diukur dengan melacak 
tingkat variabilitas jantung, tidak berubah secara signifikan dengan waktu pada tugas-tugas. Demikian pula hal ini terjadi pada hasil pengukuran pada penelitian ini, tidak terdapat perbedaan SDNN pada kedua paruh perjalanan tugas. Hal ini ditunjukkan pula dengan nilai $\triangle$ SDNN pada separuh pertama dan kedua perjalanan tugas menunjukkan adanya peningkatan, peningkatan SDNN mengindikasikan terjadi penurunan beban kerja mental (DiDomenico dan Nussbaum, 2008).

Secara individu, hanya terdapat satu masinis yang mengalami penurunan SDNN yang berarti. Kondisi ini mengindikasikan bahwa individu tersebut mengalami peningkatan beban kerja mental selama menjalankan tugas yang cukup berarti. Assessment perlu dilakukan terhadap masinis ini karena masinis ini merupakan masinis senior berusia antara 37-42 tahun dengan pengalaman sebagai masinis selama 1622 tahun dan satu masinis yunior dengan usia 27 tahun dan pengalaman 6 tahun sebagai masinis. Assessment perlu dilakukan mengingat bahwa masinis senior telah menguasai dan memahami tugas dan tanggung jawab yang dijalankannya.

\subsection{Analisis Tingkat Stres dan Beban Mental Masinis}

Berdasarkan uji statistik, dari tiga kondisi pengukuran tingkat stress terhadap 4 parameter lingkungan fisik kabin lokomotif, korelasi hanya terjadi pada temperatur pada saat bertugas $(\mathrm{p}<0,05)$ dan tingkat kebisingan setelah menyelesaikan seluruh tugas $(p<0,05)$ terhadap perubahan nilai konsentrasi SAA. Sedangkan terhadap beban kerja mental, korelasi hanya terjadi pada tingkat kelembaban setelah menyelesaikan seluruh tugas $(\mathrm{p}<0,05)$ terhadap perubahan nilai SDNN. Demikian pula pada $\mathrm{HR}_{\text {mean }}$, haya terdapat korelasi antara kebisingan pada awal bertugas yang mempengaruhi perubahan $\mathrm{HR}_{\text {mean }}(\mathrm{p}<0,05)$.

Peningkatkan persentase masinis yang memiliki konsentrasi SAA tinggi terjadi setelah menjalankan separuh pertama tugas pagi. Masinis yang mengalami penurunan SDNN 50\% diantaranya menjalankan paruh pertama tugas. Penurunan SDNN menggambarkan adanya peningkatan beban kerja mental (DiDomenico dan Nussbaum, 2011) dan kondisi ini serupa dengan kajian dari Yamaguchi dan Sakakima (2007) yang memberikan secondary task pada obyek penelitiannya dan berdampak pada peningkatan konsentrasi SAA.Namun demikian secara statistik menunjukkan bahwa perjalanan tugas tidak memberikan dampak terhadap peningkatan stres dan beban kerja. Hal ini mungkin karena perjalanan tugas selama empat jam tidak cukup meningkatkan stres beban kerja dan kelelahan mental masinis. Dalam beberapa penelitian, kajian terhadap aspek ini dilakukan pada simulator, dengan perlakuan, dan dilakukan dalam waktu yang lebih lama.

Sebagai proses stimus-respon dari stres dan strain (beban kerja mental), penurunan/peningkatan tingkat stres menyebabkan penurunan/peningkatan beban kerja mental, dan sebaliknya. Secara individu, dari 27 pengukuran HRV pada dua paruh perjalanan tugas diperoleh:

1. 12 paruh perjalanan memiliki peningkatan/penurunan tingkat stres diikuti oleh peningkatan/penurunan beban kerja mental pada ketiga indikator (SDNN dan $\mathrm{HR}_{\text {mean }}$ )

2. 16 paruh perjalanan memiliki peningkatan/penurunan tingkat stres diikuti oleh peningkatan/penurunan beban kerja mental hanya pada dua indikator

3. 14 paruh perjalanan memiliki peningkatan/penurunan tingkat stres diikuti oleh peningkatan/penurunan beban kerja mental hanya pada satu indikator

4. 12 paruh perjalanan tugas yang menunjukkan bahwa peningkatan/ penurunan tingkat stres tidak diikuti oleh peningkatan/ penurunan beban kerja mental.

Bila melihat secara individu, terdapat 15 masinis yang memiliki tingkat stres, beban kerja mental, dan kelelahan selama menjalankan tugas. Dari ke 15 masinis tersebut hanya empat masinis yang mengalami peningkatan/penurunan tingkat stres dan diikuti oleh peningkatan/ penurunan HRV.

Selama menjalankan tugas pagi masinis mengalami peningkatan tingkat stres terutama pada separuh pertama. Pada tugas pagi masinis akan menjalankan kereta melalui lintasan berbukit dan berkelok. Selain itu jadwal perjalanan ini bersamaan dengan waktu masyarakat sekitar lintasan memulai aktivitas, sedangkan lintasan yang dilalui masih belum steril. Hal ini berdampak pada tingkat konsentrasi masinis harus ditingkatkan berkaitan dengan kondisi lintasan tersebut. Dengan demikian maka jam tugas lewat tengah malam hingga dini hari berpotensi memicu stres dan beban mental masinis. Hal ini disebabkan akumulasi beban kerja yang dialami dari hari-hari sebelumnya dan belum mengalami pemulihan secara tuntas. 
Faktor sirkadian, homeostasis yang dilihat dari jam kerja, jam tidur dan terjaga, jam dan durasi tidur, serta tugas ((Noy dkk., 2011, Williamson dkk., 2011, Milia dkk 2011).

Hasil studi ini hanya berlaku di Daerah Operasional II Bandung, karena setiap Daerah Operasional/Divisi Regional memiliki karakteristik yang berbeda, baik dari kondisi lintasan, lingkungan, maupun masinis. Namun demikian kondisi lintasan di DaOp II Bandung dapat menggambarkan kondisi lintasan yang lebih lengkap, karena terdapat lintasan datar, berbukit dan berkelok, terdapat perlintasan sebidang yang tidak resmi dan tidak berpalang, dan tidak steril. Kondisi ini hampir sama dengan kondisi di DaOp dan DivRe lainnya.

\section{Kesimpulan}

Telah diketahui sebelumnya bahwa faktor yang dominan menjadi sumber stres kerja masinis di Daerah Operasional II Bandung adalah lingkungan kerja. Namun demikian dari hasil observasi diperoleh temuan bahwa kondisi ini terjadi karena tidak beroperasinya sistem pendingin pada kabin lokomotif, sehingga masinis hanya mengandalkan sirkulasi udara dari jendela lokomotif. Kondisi ini berdampak pula pada tingkat kebisingan yang tinggi dan didukung pula oleh kondisi mesin lokomotif pada saat melalui lintasan berbukit. Namun demikian kondisi ini secara umum tidak mempengaruhi tingkat stres dan beban mental masinis.

Tingginya tingkat stres tersebut dibuktikan dengan 56\% masinis memiliki tingkat Salivary $\square$ Amylase (SAA) yang berada di atas kriteria sangat stres. Bahkan tingkat stres yang tinggi dialami masinis pada saat sebelum menjalankan tugas, Kondisi ini dapat disebabkan oleh kegiatan sebelumnya sebagai aktivitas di luar tugas. Dari penelitian ini juga ditemukan bahwa perjalanan selama tugas tidak memberikan pengaruh terhadap peningkatan stres lebih lanjut.

Tingkat beban kerja mental masinis secara obyektif melalui respon fisiologis berada pada batas normal dan cenderung moderat.Dapat disimpulkan bahwa beban kerja mental masinis, yang dilihat dari Heart Rate Variability (HRV), cenderung normal. Walaupun belum ada norma/standar yang dapat digunakan sebagai acuan, hasil pengukuran menunjukkan bahwa nilai SDNN dan $\mathrm{HR}_{\text {mean }}$ masinis masih dalam rentang normal hasil penelitian-penelitian yang telah dilakukan.

Sumber stres yang dialami selama menjalankan tugas tidak mempengaruhi tingkat stres dan beban kerja dalam rentang empat jam pengukuran selama menjalankan tugas. Hal ini mungkin terjadi karena selama empat jam pengukuran tidak cukup untuk meningkatkan stres dan beban kerja mental masinis.

\section{DAFTAR PUSTAKA}

Bourdreau, P., Dumont, G., Kin, N. N., Walker, CD., dan Boivin, D.B. (2011), Correlation of Heart Rate Variability and Circadian Markers in Human. 33rd Annual International Conference of IEEE EMBS. Boston, Massachusetts USA. Hal. 681-684

Cox, T., dan Griffiths, A. (2005), The Nature and Measurement of Work-Related Stress: Theory and Practice. In J. R. Wilson, dan N. Corlett, Evaluation of Human Work, 3rd Ed. Hal. 553-571, New York: Taylor dan Francis Group, LLC

DiDomenico, A., dan Nussbaum, M. A. (2008), Interactive Effects of Physical and Mental Workload on Subjective Workload Assessment. International Journal of Industrial Ergonomic, Vol. 38, hal. 977-983

DiDomenico, A., dan Nussbaum, M. A. (2011), Effects of Different Physical Workload Parameters on Mental Workload and Performance. International Journal of Industrial Ergonomics, Vol. 41, hal. 255260

Dorrian, J., Roach, G. D., Fletcher, A., dan Dawson, D. (2006), The Effects of Fatigue on Train Handling During Speed Restrictions. Transportation Research Part F 9, hal. 243-257

Dorrian, J., Roach, G. D., Fletcher, A., dan Dawson, D. (2007b): Simulated Train Driving: Fatigue, Self-Awareness and Cognitive Disengagement. Applied Ergonomics, Vol. 38, hal. 155-166

Hancock, P. A., dan Meshkati, N. (1988): Human Mental Workload:Advances in Psychology 52. Amsterdam: Elsevier Science Publisher B.V.

Kim, G.-M., dan Woo, J.-M. (2011). Determinants for Heart Rate Variability in Normal Korean Population. Cardiovascular Disorders, hal. 1293-1298.

Kroemer, K. H., Kroemer, H. J., dan KroemerElbert, K. E. (2010): Engineering Physiology Bases of Human Factors Engineering. New York: Springer.

Landy, F. J., dan Conte, J. M. (2013): Work in the 21th Century: An Introduction to Industrial and Organizational Psychology, 4th Ed. John Wiley dan Sons, Inc.

Martinussen, M., dan Hunter, D. R. (2010): Aviation Psychology and Human Factors. CRC Press, Taylor and Francis Group.

Milia, L. D., Smolensky, M. H., Costa, G., Howarth, H. D., Ohayon, M. M., dan Philip, 
P. (2011): Demographic Factors, Fatigue, and Driving Accidents: An Examination of The Published Literture. Accident Analysis and Prevention, Vol. 43, hal. 516-532.

Mulrine, B. L., Sheehan, M. F., Burell, L. M., dan Matthews, M. D. (2011): Measuring Stress and Ability to Recover from Stress with Salivary Alpha-Amylase Levels. United States Military Academy, Department of Behavioral Sciences and Leadership.

Noy, Y. I., Horrey, W. J., Popkin, S. M., Folkard, S., Howarth, H. D., dan Courtney, T. K. (2011): Future direction in fatigue and safety research. Accident Analysis and Prevention, Vol. 43 No. 2, hal. 495-497.

Nunan, D., Sandercock, G. R., dan Brodie, D. A. (2010): A Quantitative Systematic Review of Normal Values for Short-Term Heart Rate Variability in Health Adults. Pacing Clinic Electrophysiology, Vol. 33, No. 11, hal. 1407-1417.

Paritala, S. A. (2009): Effect of Physical and Mental Tasks on Heart Rate Variability. hal.Louisiana: Louisiana State University and Agricultural and Mechanical College.

Park, S., Lee, B., dan Jeong, K. (2007). Standardized Test of Heart Rate Variability for Autonomic Function Test in Healthy Korean. International Journal of Neuroscience, Vol. 117, No. 12, hal. 17071717.

Rohleder, N., dan Nater, U. M. (2009): Determinants of Salivary Alpha Amylase in Humans and Methodological Considerations, Psychoneuroendocrinology, Vol. 34, hal. 469-485.

Rohleder, N., Nater, U. M., Wolf, J. M., Ehlert, U., dan Kirschbaum, C. (2004): Psychosocial Stress-Induced Activation of Salivary Alpha-Amylase - An Indicator of Sympathetic Activity? Ann. New York Academy of Sciences, Vol. 1032, hal. 258263.

Scanlon, V. C., dan Sanders, T. (2007): Essential of Anatomy and Physiology, 6th Ed. Davis Company.

Silva, F. P. (2014): Mental Workload, Task Demand and Driving Performane: What Relation? Procedia-social and Behavioral Sciences, Vol. 162, hal. 310-319.

Taelman, J., Vandeput, S., Spaepen, A., dan Huffel, S. V. (2008): Influence of Mental Stress on Heart Rate and Heart Rate Variability. International Federation for Medical and
Biological Engineering, Vol. 22, hal. 13661369.

Tarvainen, M. P., Niskanen, J.-P., Lipponen, J. A., Ranta-aho, P. O., dan Karjalainen, P. A. (2014). Kubios HRV- Heart Rate Variability Analysis Software. Computer Methods and Programs in Biomedicine, Vol. 113, No.1, hal. 210-220.

Taylor, S. E. (2009). Health Psychology, 7th edition. McGraw-Hill, Inc.

Uusitalo, A., Mets, T., Martinmaki, K., Mauno, S., Kinnunen, U., dan Rusko, H. (2011): Heart rate Variability Related to Effort at Work. Applied ergonomics, hal. 1-9.

Wahyuning, C.S. dan Desriyanti, A. (2011).Tingkat Stres Kerja Pada Pengendara Moda Transportasi Darat dan Kereta Api. Lembaga Penelitian dan Pengabdian Masyarakat-Itenas. Laporan Penelitian.

Williamson, A., Lombardi, D. A., Folkard, S., Stutts, J., Curtney, T. K., dan Connor, J. L. (2011): The Link Between Fatigue and Safety. Accident Analysis and Prevention, hal. 498-515.

Yamaguchi, M., dan Sakakima, J. (2007): Evaluatin of Driver Stress in Motor-Vehicle Driving Simulator Using a Biochemical Marker. Journal of International Medical Research, Vol 35, hal. 91-100.

Yamaguchi, M., Kanemori, T., Kanemaru, M., Mizuno, Y., dan Takai, N. (2003): The influence of physical stress on amylase activity in human saliva. Life Support, Vol 15, hal. 3, hal. 120-127.

Yamaguchi, M., Kanemori, T., Kanemaru, M., takai, N., Mizuno, Y., dan Yoshida, H. (2004): Performance Evaluation of Salivary Amylase Activity Monitor. Biosensor and Bioelectronics, Vol. 20, hal. 491-497.

Zoer, I., Sluiter, J., dan Frings-Dresen, M. (2014). Psychological Work Characteristics, Psychological Workload and Associated Psychological and Cognitive Requirements of Train Drivers. In I. Zoer, Towards improving workers' health by matching work and workers (hal. 40-73). Amsterdam: University of Amsterdam. 